\title{
Pengolahan Data Infrastruktur Suku Dinas Pemuda Dan Olahraga Jakarta Barat Berbasis Web
}

\author{
Web-Based Infrastructure Data Processing of West Jakarta Youth and Sports Office \\ Mulia Rahmayu ${ }^{1)}$, Rosi Kusuma Serli ${ }^{2),}$ Mochamad Farhan Aditya ${ }^{3),}$ \\ ${ }^{1)}$ Program Studi Sistem Informasi, STMIK Nusa Mandiri \\ Jl. Jatiwaringin Raya No.02 Kelurahan Cipinang Melayu Kecamatan Makassar Jakarta Timur \\ ${ }^{2)}$ Program Studi Teknik Informatika, STMIK Nusa Mandiri \\ Jl. Jatiwaringin Raya No.02 Kelurahan Cipinang Melayu Kecamatan Makassar Jakarta Timur \\ 3) Program Studi Sistem Informasi,Fakultas Teknik dan Informatika, Universitas Bina Sarana Informatika \\ Jl. Kramat Raya No. 98, Senen, Jakarta, Indonesia
}

Copyright (C2021, JITU, Submitted: 21 Desember 2020; Revised: 06 January 2021; Accepted: 30 January 2021; Published: 01 Maret 2021

\begin{abstract}
Public service is one of the most important things to ensure the goal of creating good government in a work arrangement between all components. One of the most important parts in an institution is often measured by the community through the success or failure of an event that is held and every event or event held must have infrastructure or infrastructure and facilities that are sufficiently supportive or qualified, currently at the West Jakarta Youth and Sports Office. still managing infrastructure and facilities data manually, this is what results in infrastructure management being less effective and efficient, for that by making the design of the Infrastructure and Facilities Management system is an effective way of managing infrastructure to be stored in the database This system is designed using the prototype method. This system can search for data on complaints about existing problems in infrastructure to be faster and can present data to be effective and efficient because it is website-based. Key words - infrastructure management; prototype; website
\end{abstract}

Abstrak - Pelayanan Publik merupakan salah satu hal yang sangat penting untuk menjamin tujuan terciptanya good government dalam sebuah tatanan kerja antara semua komponen. Salah satu bagian terpenting dalam sebuah institusi sering diukur oleh masyarakat melalui berhasil atau tidaknya sebuah acara yang diselenggarakan dan disetiap acara atau event yang diselenggarakan harus memiliki Infrastruktur atau Prasarana dan Sarana yang cukup mendukung atau mumpuni, saat ini di Kantor Suku Dinas Pemuda dan Olahraga Jakarta Barat masih melakukan pengelolaan data Prasarana dan Sarana secara manual, hal inilah yang mengakibatkan pengelolaan Infrastruktur menjadi kurang efektif dan efisien, untuk itu dengan pembuatan perancangan sistem Pengelolaan Prasarana dan Sarana merupakan cara yang efektif untuk proses Pengelolaan infrastruktur yang akan tersimpan ke dalam database. Sistem ini dirancang dengan menggunakan metode prototype. Sistem ini dapat mencari data pengaduan masalah yang ada pada infrasturktur menjadi lebih cepat dan dapat menyajikan data menjadi efektif dan efisien karena berbasis website.

Kata kunci - pengelolaan infrastruktur; prototype; website

\section{Pendahuluan}

Pengembangan keolahragaan dalam tatanan sistem keolahragaan nasional dikembangkan melalui tiga pilar yaitu olahraga pendidikan, olahraga rekreasi dan olahraga prestasi. Olahraga pendidikan merupakan bagian integral dari pendidikan yang dilaksanakan baik pada jalur formal maupun non formal melalui kegiatan intra dan atau ekstrakurikuler. Olahraga rekreasi bertujuan untuk mengembangkan kesadaran masyarakat untuk meningkatkan kesehatan, kebugaran, kesenangan dan hubungan sosial, sedangkan olahraga prestasi dikhususkan untuk pencapaian prestasi baik dalam kejuaraan tingkat daerah, nasional, regional maupun internasional[1].

\footnotetext{
*) Penulis korespondensi (Mulia Rahmayu)

Email: mulia.mlh@nusamandiri.ac.id
}

Menurut Peraturan Daerah Provinsi DKI Jakarta BAB X Pasal 67 Tahun 2016 "Sistem Pengadaan Prasarana dan Sarana (Infrastruktur) yang diperlukan dalam kegiatan dan/atau penyelenggaraaan keolahragaan menjadi tanggung jawab bersama Pemerintah Daerah, Organisasi Olahraga, Pelaku Usaha, dan Masyarakat sesuai lingkup tugasny."[2]

Seperti yang dijelaskan dalam BAB X Tentang Prasarana dan Sarana Olahraga Pasal 67 Ayat 3 menyebutkan bahwa Pengadaan Prasarana dan Sarana Keolahragaan yang menjadi Tanggung Jawab Pemerintah Daerah dan pemberian bantuan Sarana Keolahragaan dilakukan melalui tahapan Perencanaan, Pemeliharaan, dan Pengawasan sesuai standard dan kebutuhan yang ditetapkan dalam ketentuan peratuan Perundang-undangan. [2]

Peraturan Pemerintah Nomor : 25 Tahun 1978, wilayah DKI Jakarta di bagi menjadi 5 (lima) wilayah 
kota administratif. Wilayah kota administrasi Jakarta Barat merupakan salah satu bagian yang memiliki kedudukan setingkat dengan kotamadya Tingkat II. Walikota yang bertanggung jawab langsung kepada gubernur KDKI Jakarta berdasarkan penetapan Presiden RI No.2 Tahun 1961 tentang pemerintahan DKI Jakarta dan penjelasan undang-undang No.5 Tahun 1974 tentang pokok-pokok pemerintah di daerah, bahwa tugas, wewenang dan kewajiban Walikota adalah menjalankan pemerintah pembangunan dan pembinaan kemasyarakatan dalam wilayah.

Sarana olahraga adalah peralatan dan perlengkapan yang digunakan untuk kegiatan olahraga. Sedangkan prasarana olahraga adalah tempat atau ruang termasuk lingkungan yang digunakan untuk kegiatan olahraga dan/atau penyelenggaraan keolahragaan (UU SKN No. 3. Tahun 2005) [3]

Pusat pemerintah Kota administrasi Jakarta Barat saat ini berada di jalan Raya Kembangan No.2 Kec. Kembangan, yang sebelumnya beralamat di jalan Raya S.Parman No.2 Kec. Grogol Petamburan.

Berdasarkan hasil wawancara dengan kepala sub bagian Tata Usaha Kantor Suku Dinas Pemuda dan Olahraga menjelaskan bahwa dalam pengolahan data infrastruktur di Kantor Suku Dinas Pemuda dan Olahraga Jakarta Barat masih belum menggunakan sistem yang terkomputerisasi dengan demikian hal itu akan memperlambat kinerja serta memakan waktu yang lumayan lama.

Adapun tujuan dari penelitian ini adalah membangun sebuah sistem pengolahan data infrastruktur yang ada di Suku Dinas Pemuda dan Olahraga berbasis web sehingga menghasilkan suatu informasi yang cepat dan akurat dalam membantu dan memudahkan proses pengolahan data infrastruktur pada Suku Dinas Pemuda dan Olahraga.

Secara garis besar, ruang lingkup yang akan dibahas pada penelitian ini yaitu : Pengolahan Data Infrastuktur, Laporan Pengawasan Infrastruktur, Pengajuan Menambah alat-alat penunjang Infrastruktur, Laporan data progress infrastruktur.

Pada penelitian sebelumnya yang dilakukan oleh [4] mengenai Sistem Informasi Sarana Dan Prasarana Sekolah Berbasis Website SMK Bakti Purwokerto menjelaskan bahwa di sekolah tersebut pengelolaan barang sarana dan prasarana saat ini masih menggunakan cara manual yaitu dengan pencatatan di buku. Pengelolaan barang dengan cara seperti ini menyebabkan kurang maksimalnya dalam pengelolaan Sarana dan Prasarana yang ada. Beberapa masalah lainnya yaitu sulitnya bagian staf Wakil Kepala Sarana dan Prasarana dalam proses pencarian informasi barang, karena tidak lengkap dan detailnya data pada proses pembukuan. Oleh karena itu, barang pada Sarana dan Prasarana yang telah berpindah tempat atau dipinjam sangat sulit untuk diketahui keberadaannya. Sistem informasi berbasis website menggunakan metode kualitatif. Metode ini bersifat sistem dengan metode prototype sebagai pengembangan sistemnya. Hasil dari penelitian ini yaitu membuat suatu sistem informasi sarana dan prasarana sekolah berbasis website pada SMK Bakti Purwokerto dengan tujuan dapat membantu staf Wakil Kepala Sarana dan Prasarana mulai dari proses pencarian barang menggunakan scan QR Code, perekapan laporan hingga mengelompokkan data sarana prasarana. Kesimpulan dari pengujian Acceptance Testing atau istilah dari Beta Testing dihasilkan 88,65\% yaitu masuk ke dalam kategori sangat baik terhadap sistem yang di usulkan.

Pada penelitian lainnya dilakukan oleh [5] mengenai Rancang Bangun Aplikasi Pengelolaan Sarana Dan Prasarana Di Kantor Pos Cimahi 40500 Berbasis Web menjelaskan bahwa aplikasi Pengelolaan Sarana Dan Prasarana ini dirancang untuk memberikan keamanan dalam penyimpanan data di bidang sarana prasarana yang ada di kantor pos cimahi 40500 dan juga dalam pengelolaan data-data yang ada di bidang sarana secara terkomputerisasi. Pada landasan teori ini menjelaskan mengenai teori-teori yang digunakan dalam merancang sistem dan juga perangkat pendukung lainnya untuk proses pembuatan aplikasi pengelolaan ini. Metode yang di lakukan untuk merancang sistem aplikasi ini menggunakan metode waterfall atau air terjun. Aplikasi pengelolaan ini dirancang dengan menggunakan bahasa pemograman PHP dengan menggunakan Framework CodeIgniter, database MySQL sebagai media penyimpanan datanya. Untuk servernya di sini menggunakan apache dan untuk alat bantu perancangan berupa diagram UML (Unified Modelling Language). Dapat disimpulkan dengan adanya aplikasi pengelolaan ini karyawan dapat lebih baik lagi dalam penyimpanan data dan juga mengelola data-data sarana dan prasarana karena sekarang sistem yang ada sudah terkomputerisasi

Berdasarkan hasil dari penelitian sebelumnya dapat disimpulkan bahwa penelitian ini perlu dilakukan karena menghasilkan sebuah system yang dapat memberikan kemudahan kepada pengguna.

\section{Metode PENELITIAN}

Dalam rangka pengumpulan data untuk penelitian ini ada dua macam metode penelitian yang penulis anggap paling baik dan akurat yaitu :

\section{A. Metode Pengembangan Perangkat Lunak}

Metode yang digunakan pada pengembangan perangkat lunak ini menggunakan model prototype [6], yang dibagi menjadi Tiga tahapan yaitu

\section{Analisa Masalah dan Kebutuhan}

Dalam analisa kebutuhan dijelaskan bagaimana cara menyelesaikan dan menemukan jawaban dari suatu permasalahan atau kasus. Dalam masalah ini kantor Suku Dinas Pemuda dan Olahraga masih menggunakan sistem pengelolaan data infrastruktur masih secara manual. Hal ini dapat membuat para staff kesulitan dalam melaksanakan tugas pengawasan, pengelolaan dan pengembangan yang diinginkan secara efisien. Maka dari itu sebuah sistem pengelolaan data infrastruktur baru atau yang terkomputerisasi sangat diperlukan guna mempermudah kinerja para staff dalam hal pengelolaan infrastruktur yang ada. 
2.Desain dan Perancangan Perangkat Lunak

Untuk menggambarkan suatu rancangan yang diusulkan, pembuatan database dan pembuatan program yang disesuaikan berdasrakan kebutuhan perusahaan. Bahasa pemrograman yang digunakan adalah PHP karena bersifat dinamis, dan bias berinteraksi dengan database menggunakan MySQL karena bersifat open source dan memiliki interface terhadap berbagai aplikasi dan bahasa pemrograman, serta dalam perancangan aplikasi penulis menggunakan just in mind karena didalamnya terdapat banyak fitur untuk mendesain Mockup.

\section{B. Teknik Pengumpulan Data}

\section{Pengamatan}

Pengamatan di lakukan secara langsung di Kantor Suku Dinas Pemuda dan Olahraga serta salah satu Gelanggang Olahraga yang berada dalam kawasan pengawasan Sudin Olahraga Jakarta Barat yang beralamatkan di Jl. Cendrawasih observasi dilakukan sesuai dengan kegiatan yang berhubungan dengan masalah yang diambil. Hasil dari pengamatan tersebut langsung dicatat dan dari kegiatan Observasi dapat diketahui kesalah atau proses dari kegiatan tersebut.

2. Wawancara

Dalam penelitian ini, untuk mendapatkan informasi secara lengkap maka dilakukan suatu metode tanya jawab dengan Kepala Sub Bagian Tata Usaha Kantor Suku Dinas Pemuda dan Olahraga Bapak Alex Fernando Ali, SE mengenai semua alur yang berhubungan dengan analisa sistem Pengelolaan Infrastruktur di Suku Dinas Pemuda dan Olahraga.

3. Studi Pustaka

Selain melakukan kegiatan diatas, juga melakukan studi keputusan melalui literatur-literatur atau refrensi

\section{HASIL DAN PEMBAHASAN}

\section{A. Analisis Kebutuhan}

Dalam perancangan sistem pengolahan data infrastruktur terdapat dua pengguna yang saling berhubungan dalam lingkungan sistem, yaitu: Bagian Staff dan Pengawas. Kedua pengguna tersebut memiliki karakteristik sesuai dengan sistem yang berbeda dan memiliki kebutuhan informasi yang berbeda, seperti digambarkan use case di bawah ini :

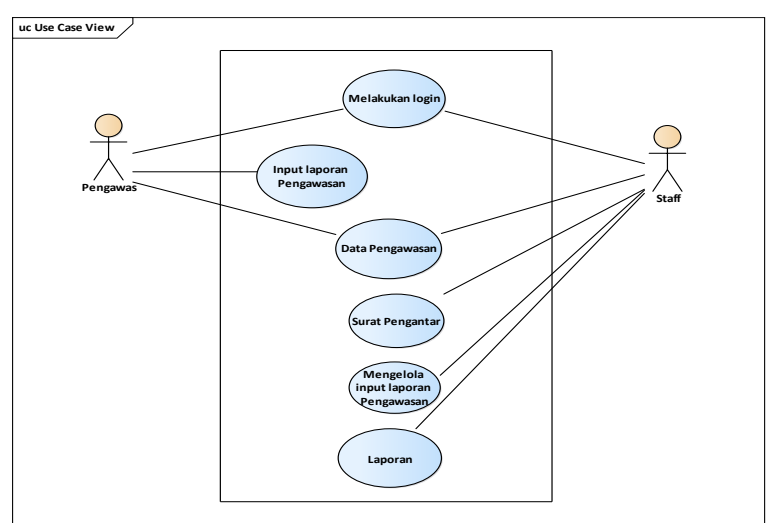

Gambar 1. use case kebutuhan pengguna

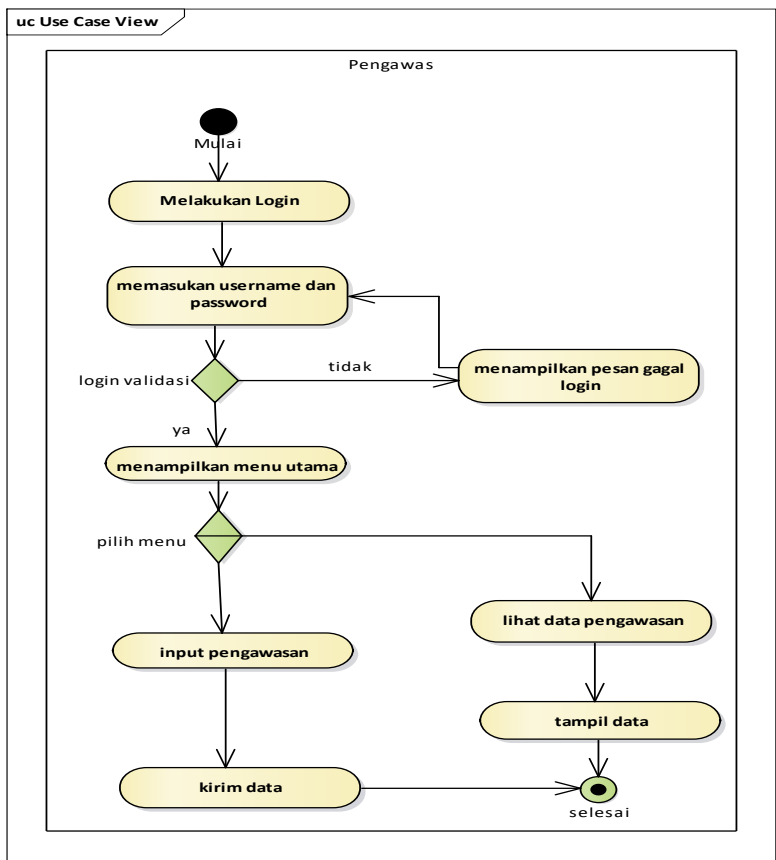

Gambar 2. Activity Diagram Bagian Pengawas

\section{B. Rancangan Prototype \\ 1. Pengawas}

Pada menu form login pengawas perlu memasukan NIP dan Kata sandi untuk masuk ke halaman selanjutnya
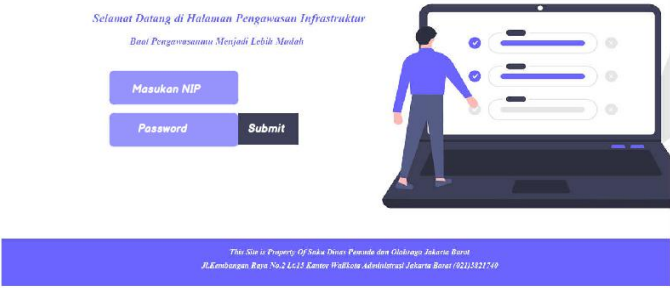

Gambar 3. Form Login Pengawas

Pada tampilan halaman utama Terdapat sub-menu seperti informasi, Buat laporan pengawasan dan Home

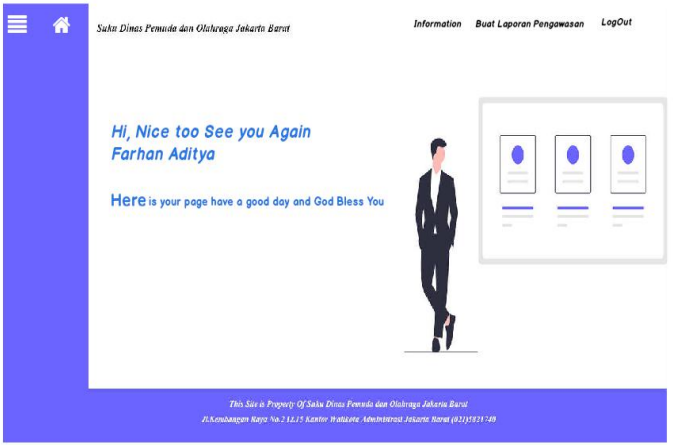

Gambar 4. Tampilan Halaman Utama Pengawas 
Tampilan menu Buat Laporan, pada tampilan ini pengawas dapat memasukan laporan tertulis dan juga dalam bentuk foto untu dikirimkan ke bagian staff di Kantor Suku Dinas Pemuda dan Olahraga

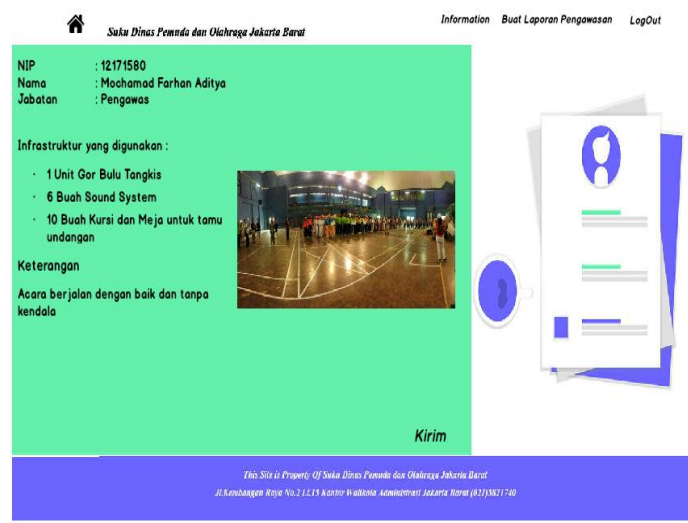

Gambar 5. Tampilan Halaman Buat Laporan Pengawasan

\section{Staff}

Tampilan Form Login Bagian Staff, Perlu memasukan NIP dan Password untuk masuk ke halaman aplikasi

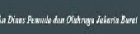

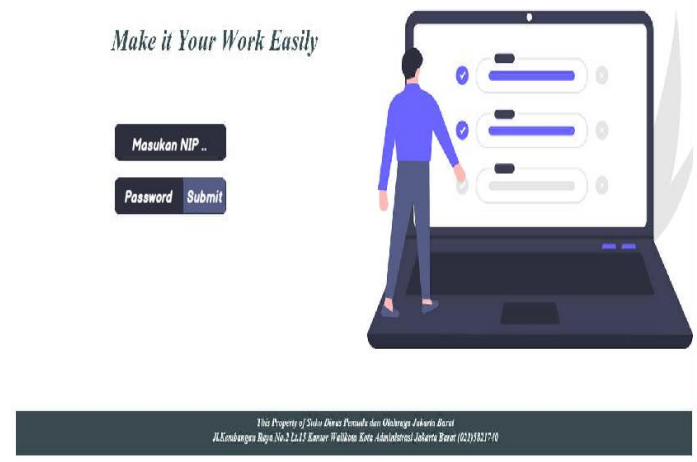

Gambar 6. Form Login Bagian Staff

Tampilan Halaman Utama bagian Staff, terdapat sub menu seperti information, Buat / Cetak Surat Pengantar dan Kelola data Pengawasan dan Laporan

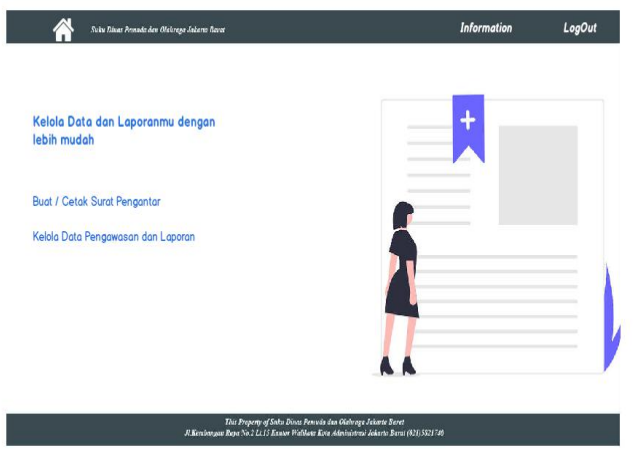

Gambar 7. Tampilan Halaman Menu Utama Bagian Staff

C. Perancangan Perangkat Lunak

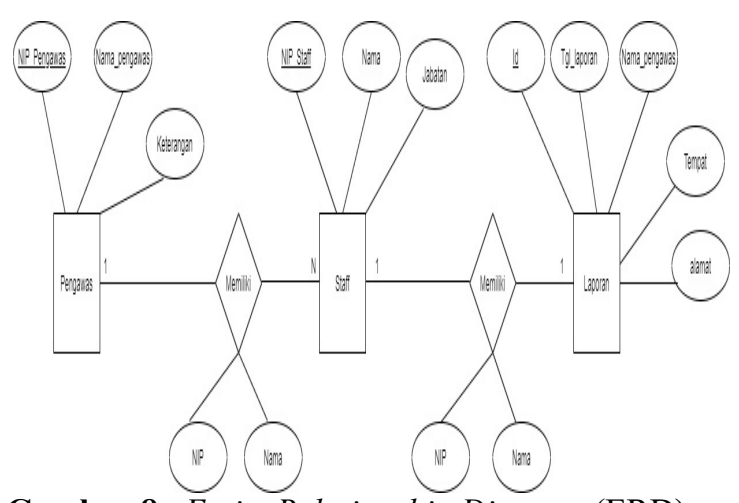

Gambar 8. Entity Relationship Diagram (ERD)

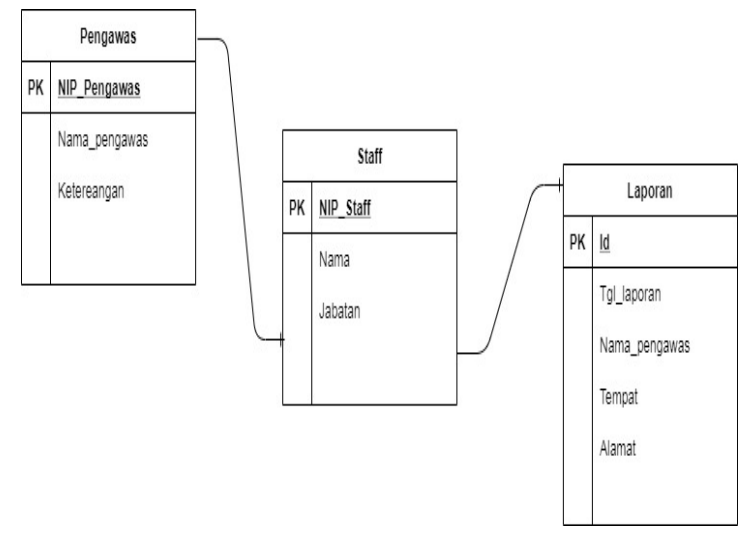

Gambar 9. Logical Record Structure (LRS) 


\section{Sequence Diagram}

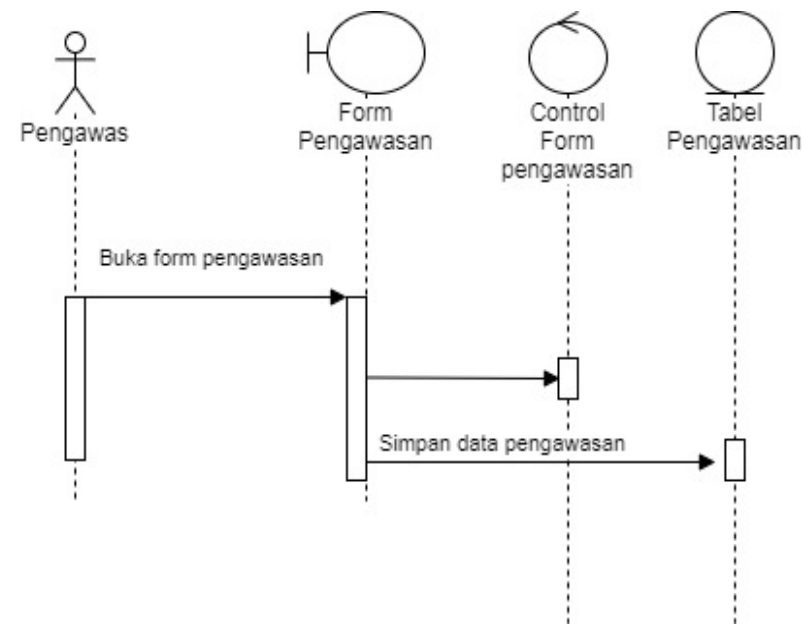

Gambar 10. Sequence Diagram Bagian Pengawas

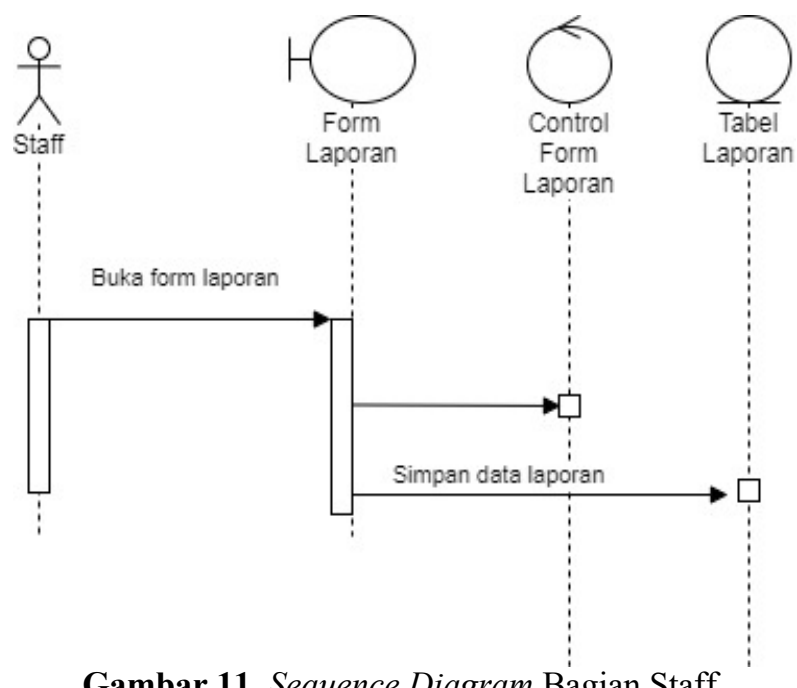

Gambar 11. Sequence Diagram Bagian Staff

\section{KESIMPULAN}

Dari hasil pembuatan sistem Pengolahan Data Infrastruktur Suku Dinas Pemuda dan Olahraga Jakarta Barat berbasis web, maka dapat disimpulkan bahwa Pembuatan perancangan sistem informasi Pengolahan Infrastruktur pada Suku Dinas Pemuda dan Olahraga Jakarta Barat merupakan sarana yang efektif untuk proses pencatatan data laporan infrastruktur, Pembuatan Perancangan Sistem Infromasi Pengolahan Data Infrastruktur pada Suku Dinas Pemuda dan Olahraga dapat mencari data laporan infrastruktur menjadi lebih cepat serta dapat menyajikan laporan data Infrastruktur menjadi lebih efektif fan efisien.

Terdapat beberapa saran yang mungkin dapat membantu agar perancangan sistem ini dapat bekerja secara optimal yaitu diharapkan memback updata setiap selesai penginputan laporan yang terjadi untuk melindungi data, sebaiknya diadakan Pelatihan / Training bagi user yang akan menjalankan sistem serta perlu adanya Perawatan (maintenance) terhadap Hardware maupun Software yang teratur dan rutin.

\section{UCAPAN TERIMA KASIH}

Penelitian ini tidak akan berjalan lancer tanpa adanya pihak yang telah membantu, untuk itu ucapan terima kasih disampaikan kepada Bapak Alex Fernando Ali selaku Kasubbag Tata Usaha SUDIN Pemuda dan Olahraga Jakarta Barat serta Staff / karyawan di lingkungan SUDIN Pemuda dan Olahraga Jakarta Barat.

\section{DAFTAR PUSTAKA}

[1] B. Setiawan, R. S. Widjaja, and S. Nugroho, "Perancangan Sistem Pendukung Keputusan (SPK) Untuk Menentukan Kelaiklautan Kapal," Pros. Semin. Nas. Manaj. Teknol. X, no. ISBN: 978-979-99735-8-0, pp. 1-7, 2009.

[2] M. A. Fadlun, K. Arivanty, H. W. S, and R. Amalia, "Sistem Pendukung Keputusan Untuk Menentukan Penerima Beasiswa Bank BRI Menggunakan FMADM (Studi Kasus: Mahasiswa Fakultas Teknologi Industri Universitas Islam Indonesia)," Semin. Nas. Apl. Teknol. Inf., vol. 2009, no. Snati, pp. 62-67, 2009.

[3] Sadi, "Peran Pemerintah TerhadapPengembangan Olahraga Pariwisata Untuk Peningkatan Perekonomian Masyarakat," Pros. Semin. Nas. IPTEK Olahraga, pp. 1-8, 2018.

[4] A. K. bagus Priono Ari, Krisbiantoro Dwi, "SISTEM INFORMASI SARANA DAN PRASARANA SEKOLAH BERBASIS WEBSITE SMK BAKTI PURWOKERTO,” vol. 2, no. $1,2020$.

[5] M. Rahmatuloh, S. Nirwan, and R. Mauludy, "Rancang bangun aplikasi pengelolaan sarana dan prasarana di Kantor Pos Cimahi 40500 berbasis web," Tek. Inform., vol. 11, pp. 1-8, 2019.

[6] W. Nugraha and M. Syarif, "Penerapan Metode Prototype Dalam Perancangan Sistem Informasi Penghitungan Volume Dan Cost Penjualan Minuman Berbasis Website," JUSIM (Jurnal Sist. Inf. Musirawas), vol. 3, no. 2, pp. 94-101, 2018, doi: 10.32767/jusim.v3i2.331. 